\title{
Misunderstandings of Capability Approach: Towards Paradigm Pluralism
}

\author{
Sylvain K. Cibangu \\ Loughborough University School of Business and Economics \\ Richard Morris Building, Loughborough, UK \\ fscib@uw.edu
}

\begin{abstract}
Capability approach figures among the most prominent approaches of social science disciplines. One reason for this is that in a world plagued by daunting inequalities and repressions the term capability presents a whole host of potentials. Another reason is that the failures or shortcomings encountered in development studies the last several decades have created something of a vogue for capability approach both in academia and industry. In the meantime, however, capability approach represents one of the most misunderstood and misused approaches of modern day times. One most pervasive misunderstanding or misuse comes with the idea that capability approach is unable to provide a definite, exhaustive list of capabilities nor to achieve measurable units of development. This idea is further compounded by the fact that Sen $(1999,2009)$ himself the originator of capability approach has invariably dismissed the discussions concerned with list and measurability. The present paper aimed to highlight the core nature of capability approach, while dispelling the misunderstandings surrounding it. Content analysis was conducted to appraise how capability approach was presented. Sen works were thus perused in light of a wider social science literature, with a focus on methodology. This is mainly because development studies is an interdisciplinary field. In so doing the paper was able to reposition capability approach as an interpretive, qualitative approach. It was thus realized that authors continue to misuse and view capability approach through the lens of quantitative research. It was also realized that interpretivism is by no means defined or evaluated based on the ability to supply a list of specific items and the measurability thereof. The paper suggested some paths for future research.
\end{abstract}

\section{Keywords: Capability, measurement, operationalization, framework, positivism, interpretivism, paradigm}

\section{Introduction}

A casual Google Scholar search reveals an explosive rise in the bodies of knowledge relative to development studies, with capability approach becoming an approach of choice. In effect, one line of work that has been gaining momentum

is scholarship over the last several decades concerning "capabilities," spearheaded by Amartya Sen's and Nussbaum's writings... Capability scholars emphasize that an individual's income, or some other measure of her material resources, is an inadequate indicator of her quality of life. (Adler \& Fleurbaey, 2016, p. 2)

As noted in this statement, with its emphasis on individual freedoms or quality of life, capability approach appeals to countless individuals and organizations. To that effect, capability approach is found to be a multipurpose and multidisciplinary approach (Robeyns, 2017). At the same time, however, Adler and Fleurbaey (2016) cautioned, "it is our firm conviction that real progress in the [methodological] tools we use for designing policy [on capabilities] requires a wider methodological range [emphasis added]" (p. 17). It is increasingly apparent among critics that one-size-fits-all methodology is counterproductive if not destructive; capability approach literature should not be an exception. Particularly worth noting is the recognition that, as Chiappero-Martinetti, Budd and Ziegler (2017) reminded us, "capability approach has... emerged as a critique of traditional conceptions and measurements of economic development" (p. 141). It is the nature of capability approach to not just call into question the idea of development, but even more so to challenge the methodologies spurring the concept measurement.

Although awareness about methodological discussions has been raised since early critical accounts of capability approach (Alkire, 2002, 2005a, b, 2007, 2008, 2010a, b, c; Alkire \& Black, 1997; Alkire, Qizilbash, \& Comim, 2008; Qizilbash, 2006; Robeyns, 2005, 2009), subsequent conversations have had little to no effect in ways of engaging in or following up on capability approach relations with or contributions to research methodology scholarship (Adler \& Fleurbaey, 2016; Alkire, 2016; Hirai, Comim, \& Ikemoto, 2016; Loots \& 
Walker, 2016; Qizilbash, 2011, 2012, 2013, 2016; Robeyns, 2016). Such a methodological stalemate has also been exacerbated by the fact that to no small degree development studies is enmeshed in discussions of and contributions to evaluations and measurements of development impacts (Bamberger, 2000; Engel, 2017; Holland \& Campbell, 2005; Johnson \& Rasulova, 2017; Mayoux \& Chambers, 2005; van der Mark, Conradie, Dedding, \& Broerse, 2017; Skovdal \& Cornish, 2015; Vicari, 2014). This has resulted in positivism and its tenets being imperial(istic) and toxic in capability approach scholarship as well as development studies. More strikingly, capability approach literature has seen an emphasis being laid on not only improving measurement but expanding or outlining lists of capabilities (Nussbaum, 1997, 2000, 2003, 2006a, b, 2011), domains of capabilities such as education, business, health, community, etc. (Ibrahim, 2006, 2017; Enderle, 2013; Venkatapuram, 2011, 2014; Walker \& Unterhalter, 2007) as well as topics of human behaviours such as emotion, shame, fear, forgiveness, etc. (De Herdt, 2008; Nussbaum, 2013, 2014, 2016).

Despite unremitting calls for a distinction between capability approach and quantitative research philosophy (Adler \& Fleurbaey, 2016; Alkire, 2002; Nussbaum, 1997, 2000, 2006b; Sen, 1960; Simon et al., 2013), a conflation of positivistic, quantitative, or lab-like views with capabilities has persisted (Hirai, 2017; Hirai, Comim, \& Ikemoto, 2016; Robeyns, 2016). Little wonder that the specifics of qualitative research methodology and their relations with and centrality in capability approach as well as the unmanipulated real world of the researched have been shunned. As Alkire (2016) explained, the demand for measurement is one of the most embattled pressures put on capability approach. This is largely because "a resource-based [or any kind of] measure is not value free" (Alkire, 2016, p. 618). Yet, the role of researchers is not (just) to manipulate, control and measure (the capabilities of) the researched or others, but rather to immerse themselves in and/or unveil the real world (experiences) of the researched. Indeed, qualitative research is a research that "will no longer accept the notion that one group of people can 'know' and define (or even represent) 'others'" (Denzin \& Lincoln, 2018c, p. 33).

Research that pursues positivistic or measurement agendas is less likely to be critical/analytical. Positivistic research is noted for its "simplification, reification and abstraction" (Fukuda-Parr, Yamin, \& Greenstein, 2014, p. 107) induced by quantitative research. As Denzin and Lincoln (2018c) insisted, structures of inequality or oppression cannot be legitimated or bypassed if researchers claim to make the world a better place. As Lindlof and Taylor (2011) suggested, failure to discuss the methods governing research can render the researcher complacent with or contributive to the structures of dominations. More specifically, "without a clear sense of the epistemological and ontological commitments of those who work within the field [such as development studies], much is blurred" (Clandinin, 2016, p. 11). Most work produced on capability approach hardly discusses methodological underpinnings, giving free rein to misunderstandings and wrong expectations. Few analysts dispute (Robeyns, 2017) that capability approach has been dogged by fixed misunderstandings. Methodological discussions should not be kept on the back burner, "never should research start by choosing a method before considering... what theoretical frameworks [or worldviews] to draw on [emphasis added]" (Hansen \& Machin, 2013, p. 6). One cannot best select and implement capability approach without digging deeper into the worldviews or methodologies beneath it.

For simplicity sake, this paper focused primarily on Sen capability approach. While capability approach was technically established in the 1980s and 1990s with Sen (1981, 1982, 1984a, b, 1985a, b, 1987, 1988, 1989, $1992,1993,1995,1997,1999)$ systematic departure from the notion of development based on abstract metrics to that of development seen as expansion of substantive freedoms, it has risen to fame in the early $2010 \mathrm{~s}$ with the upsurge of inequalities within and between nations as well as the continual inefficiencies of and debates over development indexes needed for the measurement and eradication of global poverty (Alkire et al., 2015; Lange \& Klasen, 2015; OECD, 2011). Indeed, the various challenges encountered in the implementation of The Millennium Development Goals (2000) and more particularly in the newly adopted Sustainable Development Goals (2015) have brought capabilities in greater focus.

Objectives: One objective of this paper was to inquire into the core nature of capability approach needed to avoid the misunderstandings that have been plaguing this approach. As Sen (2009) clarified, "it is important to emphasize certain specific features of this approach that should be clarified at the outset, since they have sometimes been misunderstood or misinterpreted" (p. 232). Sen (2009) went on saying, "capability approach is a general approach, focusing on information on individual advantages, judged in terms of opportunity rather 
than a specific 'design' for how a society should be organized" (p. 232). To preempt misunderstandings, capability was proposed as a worldview or underlying approach shedding light on the range of opportunities made available to individuals or societies.

Importance of the study: The importance of the study undertaken in this paper lies in the idea that "capability approach is a field that is notoriously prone to misunderstandings, in part because of its interdisciplinary nature, but also because the terminology differs somewhat between different authors [emphasis added]" (Robeyns, 2017, p. 19). As noted earlier, that capability approach is susceptible to misunderstandings was clearly denounced by Sen (2009) himself. One reason that authors have a penchant for misunderstanding capability approach might be the popularity of the approach. While moves towards eliminating misunderstandings around capability approach have been made in capability approach literature (Alkire, 2016; Robeyns, 2017), a focus on the methodological discussion of capability approach proves to be thin. As explained above, this paper was making a contribution by looking into capability approach from the perspective of methodological worldviews, namely qualitative vs quantitative paradigms. For an advanced discussion of paradigms, Lincoln, Lynham and Guba (2018) analysis is recommendable. This is because research tends to be guided by "a paradigm ... a common set of methodological assumptions or a particular epistemology" (Denzin \& Lincoln, 2018d, p. 97). Just like any scholarly approach, capability approach entails a set of methodological underpinnings that authors need to be aware of, while doing research on capability. Without a look into and control over methodological assumptions, capability approach literature becomes an essential tool for positivistic imperialism.

Clarification of terms: Four terms were central to this paper and thereby needed clarification. First, methodology was understood in this paper as the foundational philosophy, paradigm, philosophical system, background, or leading worldview along the lines of which a given research was consciously or unconsciously designed and implemented. As Denzin and Lincoln (2018a) wrote, "paradigms represent belief systems that attach the user [researcher] to a particular worldview" (p. 12). Research presupposes a philosophical system under which the researcher determines the research and its priorities. Second, method was a particular strategy used to apply one or more dimensions of a research. A method could be interchangeable with or at least conducive to a research's paradigm. This was because a method was a function or manifestation of the paradigm or worldview espoused. Third, development entailed an expansion of the freedoms needed for an individual to live a better and fuller life (Sen, 1999, 2009, 2012). Thus, development involved a fuller human actualization of concerned individuals. Fourth and last, capability (Sen, 2009, 2012) embraced the range of abilities or opportunities needed by a person in order to live a better and fuller life. While the word capability could be used in the singular - as was the case in this paper - it was a fundamentally plural concept due to the multifarious nature of human actualization. The idea being, not one capability supplanted the complex endeavour of social human fulfillment. Also to clarify, this paper took interpretivism and qualitative research as interchangeable (details below). For consistence sake, the paper used the word interpretive, qualitative research (Denzin \& Lincoln, 2018a, b, c) to indicate interpretivism. The rest of the present paper is organized into three sections: (1) literature review, (2) method, and (3) results and discussion - along with a conclusion and recommendation section.

\section{Literature Review}

Just like anything else, research does not grow out of the vacuum. Two foundational worldviews have come to characterize the methodological background in and from which scholarly work is completed, that is: positivism and interpretivism. Exposure to or awareness of positivism is indispensable in part because "the positivist and post positivist paradigms provide the backdrop against which these other paradigms and perspectives operate" (Denzin \& Lincoln, 2018d, p. 98). On no account is capability approach immune from underlying methodological assumptions.

Worldviews or paradigms: Positivism is a worldview marked by knowledge that is predictable, indisputable and positive - regardless of contexts. Positivism has received an array of appellations, such as logical positivism, empiricism, rationalism, solipsism, Cartesianism, welfarism, etc. Proponents of positivism 
(Habermas, 1968/1971) ${ }^{1}$ hold that scientific knowledge is acquired by way of experiment and observation, independently from human values, opinions, contexts, feelings and the like. As Friedman (1999) wrote, the concept verifiability also called predictability or replicability is what gives meaning to scientific propositions. The concept positivism came to prominence with the book of the 18th -19th century sociologist Auguste Comte (Comte, 1848/1998) written about positivism. In this book, social science inquiry was designed to produce positive or indubitable propositions in the same manner as inquiry conducted in natural sciences. The book at least the concept positivism was further brought into vogue by Durkheim (1895/1982) with his consideration of sociology as social physics. So science was believed to replicate and entail indubitable facts, in lieu of opinions, feelings, emotions and experiences. As Van der Tuin (2013) elucidated, "when I refer to positivism, its totalizing epistemological ideal should be kept in mind, that is, it should be remembered that its goal is to produce universal truths that stem from allegedly disembodied researchers [emphasis added]" (p. 101). Because knowledge was believed to be replicable or predicable, it was implemented from one context to another, irrespective of location and time. The totalizing or totalitarian idea is the idea that knowledge produced by researchers is applicable to and representative of all individuals or units irrespective of contexts, experiences and local or personal particularities. In more ways than one, positivism is at odds with capability approach.

The second underlying research worldview after positivism is commonly called interpretivism, but sometimes termed interpretativism or interpretationism (Collier \& Elman, 2008; Denzin \& Lincoln, 2018a, b, c; Eberle, 1999). Interpretivism has grown to embody a constellation of trails, depending on where the emphasis is being placed, such as phenomenology, discourse analysis, hermeneutics, constructionism, Marxism, historicism, etc. Interpretivism gained popularity with the adjective interpretive, which came from an English translation of the German phrase "verstehende Soziologie" (Weber, 1921/2002, p. 8) literally meaning: understanding sociology (details below). Understanding sociology was a sociology proposed by German sociologists Max Weber (18641920) and George Simmel (1858-1918) with the goal to understand individuals from their own perspectives (Simmel, 1908; Weber, 1949, 1921/2002). It bears mentioning that Marx (1845/1978) used the verb to interpret as the task of philosophers (or researchers) when he said "Die Philosophen haben die Welt nur verschieden interpretiert, es kömmt drauf an, sie zu verändern (Philosophers [researchers] have only interpreted the world in different ways, it is important to change it (emphasis in original)]" (p. 7). The task of researchers to interpret the world is incomplete without changing it. Thus, understanding social research was suggested to change the world by reversing the traditional top-down social research wherein individuals and their societies were regarded as passive and second-hand witnesses, based on a deductive, context-free and distant approach of the researcher. Clearly, interpretive social research presupposes, as Denzin and Lincoln (2018b) underlined, "the avowed humanistic and social justice commitment to study the social world from the perspective of the interacting individual [emphasis added]" (p. xvi). Unsurprisingly, the changing or transforming features of interpretive social research are nothing less than the gist of capability approach. Positivism and interpretivism affect research and its design more than usually reported and thought. As Bates (1999) elaborated, researchers are encouraged to be aware of the worldviews underlying research and methods thereof. This statement is not too far away from situations where the worldviews beneath research evolve into ironclad stereotypes with authors becoming unreceptive to and unaware of one another.

Properties of worldview: As Denzin and Lincoln (2018a) elicited, "if paradigms are overarching philosophical systems denoting particular ontologies, epistemologies, and methodologies one cannot move easily from one to the other" (p.12). As they affect research, worldviews carry specific properties, of which two most important bear consideration. First among the properties of worldview is the fact that two worldviews cannot be seen or adopted at the same time. This is due to the nature of human brain in that one cannot focus on two separate points at the same time. The best illustration of this is with the world-famous Rubin vase (see Figure 1) -presented by Danish psychologist Rubin (1915, pp. 30-31). The picture illustrates the inability of humans to focus on two separate dots simultaneously. The interpretation of the picture depends on the view taken by the researcher.

\footnotetext{
${ }^{1}$ It bears clarifying that although Habermas is not a positivist, he provided one of the best explanations of positivism (1968/1971, pp. 65-186). Equally worth clarifying is the idea that post-positivism is not the same as positivism (see Morgan 2007, p. 61).
} 
Figure 1: Rubin Vase: Two faces or A cup

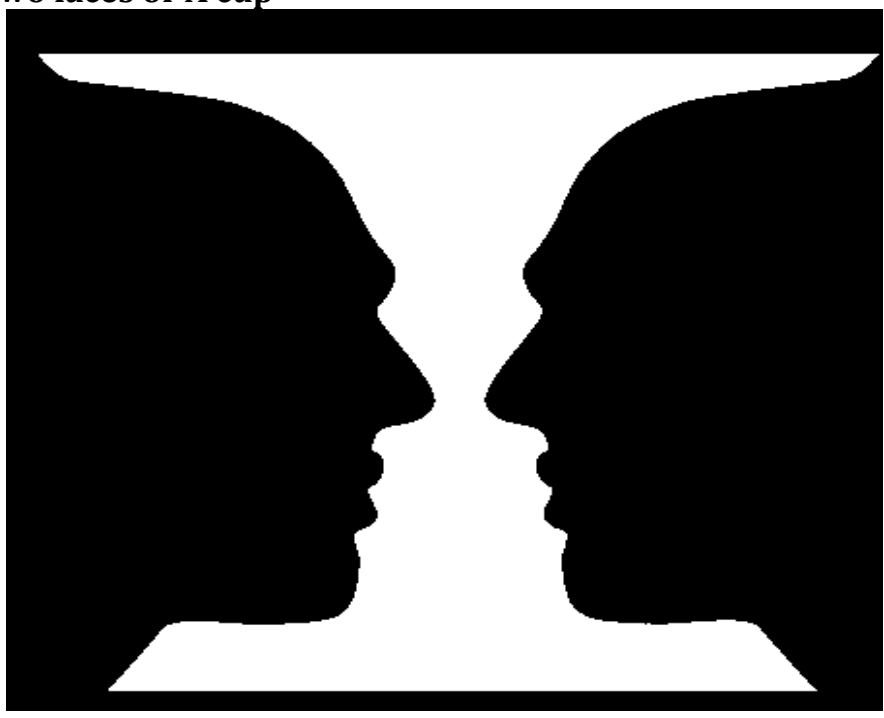

The second property of worldview has to do with the phenomenon that there is no such thing as clean worldview. Every worldview comes with or derives from a specific background, direction, or angle. One example is with the rabbit-duck picture (Jastrow, 1901, pp. 283-295; Figure 2) ${ }^{2}$-- popularly attributed to Wittgenstein (1953/1958, p.194) -- which can be seen either as a duck or as a rabbit, depending on the direction or background of the viewer or researcher.

\section{Figure 2: Duck-rabbit picture}

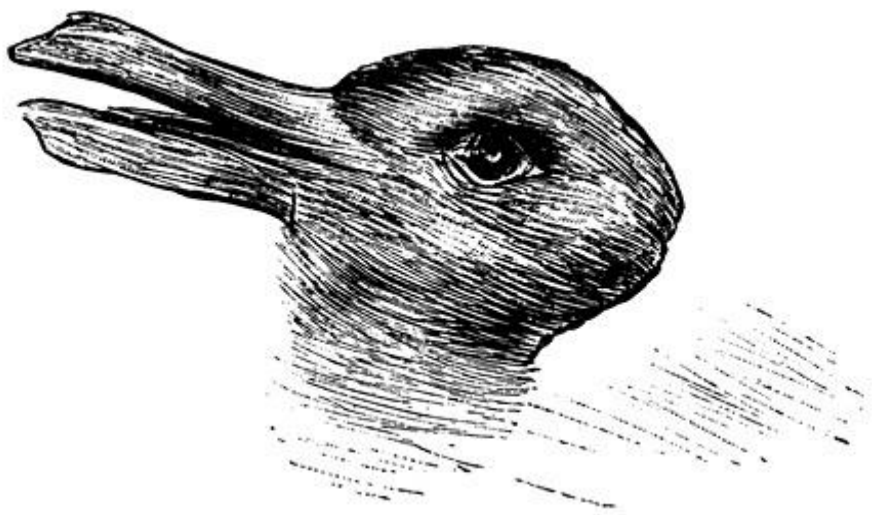

This means that the angle inflicted to research is not a matter of a good vs bad researcher. The extent to which the distinct properties of a worldview affect a person's reasoning has been confirmed by Guba and Lincoln (2005) when they posited that while positivism and interpretivism cannot be confounded, they have each seen a surge of diversity in the methods or lines of thoughts adopted. Still, diversity does not signify lack of distinction. In fact, Guba and Lincoln (1988) employed the concept water and oil to explain the dyad positivism and interpretivism in the sense that they can very well overlap, based on the research being done, but overlap is not the same as confusion or equivalence. All research is uncertain, since research is dependent on the methods adhered to, contexts involved and worldviews held. For example, Heisenberg $(1927,1930 / 2001)$ described scientific knowledge with German words as strong as Ungenauigkeit, Unbestimmtheit and Unsicherheit -- all of which connote the idea of uncertainty, indeterminacy, inexactness, inaccuracy, or imprecision.

\footnotetext{
${ }^{2}$ Advanced analysis reveals that the rabbit-duck picture arguably originated in an anonymous German article published around the turn of the 19th century (Welche Thiere, 1892, p. 147).
} 
Misunderstandings about paradigms: Reviews of social science materials display a number of misunderstandings attributed to positivism and interpretivism. This is largely because each worldview or paradigm has its own history and attendant interpretations of what science or research entails.

Positivistic knowledge. While positivism has had a significant impact on research across scientific disciplines, it is beset with misunderstandings, of which three most dominant bear attention here. The first dominant misunderstanding surrounding positivism is the belief that positivistic knowledge is certain - hence the word positive. Yet, what characterizes scientific knowledge is relativity or contextuality. As Popper (1963/2002) contended, "the criterion of the scientific status of a theory is its falsifiability, or refutability, or testability [emphasis in original]" (p. 48). This confirms a principle foundational to positivism yet often forgotten that science does not seek absolute concepts. Most pertinently, regarding scientific or positive knowledge, Comte (1830) one of the founders of positivism placed an emphasis on "l'impossibilité d'obtenir des notions absolues [the impossibility to obtain absolute concepts]" (p. 4). Positivism is not (about) absolutism. As Bridgman (1927) stated, "all our knowledge is relative" (p. 25). This is not saying that research cannot provide valuable knowledge, but that relativity is the lynchpin of scientific knowledge. As Wallach (2015) noted, "physicists talk in terms of probabilities and uncertainties, not absolutes [emphasis added]" (p. 4). This aspect of physics defeats the widespread belief that "qualitative research may be viewed as soft science" (Denzin \& Lincoln, 2018a, p. 11) and quantitative research as hard science (Hammersley, 2013, Smith, 1998, 2005a, b). This is because "situated knowledge ... is located within a historically specific culture. Scientific knowledge is no exception" (Smith, 1998, p. 4). Scientific research is characterized by contextuality or relativity.

The second misunderstanding related to positivism centres around the universality of knowledge. Universality implies the idea that knowledge is applicable and predicable from context to context, regardless of the particularities dealt with. One direct consequence stemming from the disregard of particularities is with endogeneity. Put simply, endogeneity is a paramount theory of quantitative research (Reeb, Sakakibara, \& Mahmood, 2012) premised on the belief that a sample's findings or conclusions ought to account for the variability internal or endogenous (hence endogeneity) to the larger population, in connection with the topic or phenomenon being investigated. Endogeneity is variedly called sampling error or "sample representativeness, meaning that when the process of selecting the sample has been performed properly, the sample will often have characteristics similar to those of the population [emphasis in original]" (Sotos et al., 2007, p. 101). However, most studies of quantitative or positivistic research tend not to report the accuracy of a given sample in reference to the larger population, giving rise to a rampant misunderstanding. The misunderstanding results in all investigated data and ensuing conclusions being treated as if they were an accurate reflection of the larger population, which for development studies covers 6 billion plus inhabitants, the world population. This is because endogeneity leads to the error of confusing statistical significance with practical significance also known as the law of large numbers. In other words, "people confuse the sample and the population distributions, believing that any sample must be very similar to the population, regardless of its size and therefore extrapolating the law of large numbers [emphasis in original]" (Sotos et al., 2007, p. 101) or proportions found in selected sample. Capability approach measurements and indeed any measurements should reflect the variability of the global or larger population if they claim to be quantitative studies.

The third and last misunderstanding associated with positivism is concerned with the belief that positivism yields rationality or rational knowledge. Because of this, another word used to designate positivism is rationalism. Nonetheless, scores of critics have dismissed the rationality or claimed reason of positivism. For example, Marx (1867/1977) showed rationality to be a function of the manipulation of the poor by individuals being in power whereas Horkheimer and Adorno (1947/1972) used instrumental or manipulated reason to indicate the flaws of reason and of its claims to enlightenment and progress. Of interest here is the etymology of the English term rationality. Rationality springs from the Latin word ratio, which is akin to the Greek word

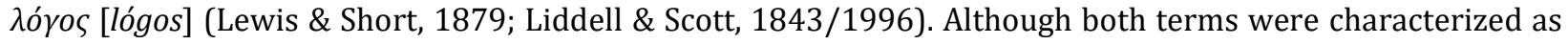
infallible or set-in-stone entities in the Enlightenment era they are not as rational as commonly believed. For example, apart from the idea of reason, logos denote instances such as fable, story, tale, expression, opinion, conversation, chitchat, prose, speech, etc. -- things that Enlightenment champions (see Bacon, 1620/1889; Descartes, 1637/1987) decidedly regarded as unsuited to rational knowledge. Equally, besides reason, the Latin term ratio stands for affairs, business, matters, interests, etc. Obviously, fables and interests can betoken 
some of the most irrational endeavours of social reality. In brief, as part of their prime meanings, logos and ratio contain irrational items such as feelings, opinions, interests, etc.

Interpretivistic knowledge. Interpretivism has been receiving recognition among researchers (Denzin, 2014; Denzin \& Lincoln, 2018a, b, c, d), but it has also been the object of three most recurrent misunderstandings. The first most recurrent misunderstanding involving interpretivism or interpretivistic knowledge revolves around the subjective vs objective binary, with interpretivism being depicted as subjective and positivism as objective. While interpretivism aims to peer deep into the subjective or lived dynamics of the phenomenon under study, it is not reducible or equivalent to subjectivism. This is because the utmost purpose of qualitative inquiry is "to discover patterns that are hidden in the details [emphasis added]" (Patton, 2015, p. 11). In fact, the purpose of interpretivism is to unearth the systematic patterns lingering beneath the lived experiences of a given phenomenon or topic. Moreover, it is widely accepted that the divide objective vs subjective, realistic vs unrealistic, inductive vs deductive, factual vs sensual and the like is a misleading rendition of both positivism and interpretivism (see Babbie, 2016; Bryman, 2016; Bryant, 2017). The most vivid description of this debate can be found with French anthropologist Lévi-Strauss (1978/1995) notable remark, when he said,

The real gap, the real separation between science and what we might as well call mythical [subjective] thought ... occurred in the seventeenth and eighteenth centuries. At that time, with Bacon, Descartes, Newton, and the others... it was thought that science could only exist by turning its back upon the world of senses... whereas the real world was a world of mathematical properties which could only be grasped by the intellect and which was entirely at odds with the false testimony of the senses. (pp. 5-6)

In no unclear terms, Lévi-Strauss (1978/1995) continued,

Contemporary science is tending to overcome this gap and... more and more the sense [subjective] data are being reintegrated into scientific explanation... Take, for instance, the world of smells. We were accustomed to think that this was entirely subjective, outside the world of science. Now the chemists are able to tell us that each smell or each taste has a certain chemical composition and to give us the reasons why subjectively some smells or some tastes feel to us as having something in common. (pp. 6-7)

As articulated in the above statements, sensory or sensual data are proven not only to be entirely scientific, but to be the object of scientific explanation and formula. Popper (1994/1996a) repudiated the idea of social sciences regarded as a manifestation of subjective phenomena devoid of realism and objectivity. Popper (1994/1996a) propounded that objective knowledge or fact is not an end in and by itself, nor an accomplishment found or enshrined in an individual researcher, but a combination of independent, physical and objective entities, such as institutions, venues, bodies of literature, communities, associations, etc. that criticize or confirm a researcher's suggested theories or concepts.

Most importantly, the English term objective derives from the Latin verb objicere, which is composed of two particles: $o b$, meaning: with, alongside, by; and jacere, standing for: to expose, present, throw, bring forth, etc. (Lewis \& Short, 1879). Object typifies something being exposed, it does not signify the idea of absolute propositions or truths. Equally, the English term subjective springs from the same Latin word (jacere), with the prefix sub, meaning in front, before, there, etc. Subject carries the same meaning of setting something in front, exposing, bringing forth, etc. In no way does the etymology display an idea of absolutist or infallible proposition or truth. Scientific, objective, or subjective knowledge is by definition expository or open not locked or closed. Indeed, according to Comte (1830), a seminal figure of positivism, positive knowledge can very well include and apply to social phenomena. To preempt a misrepresentation of scientific knowledge, Comte (1830) clarified,

La philosphie positive, dans laquelle je comprends l'étude des phénomènes sociaux aussi bien que de tous les autres, désigne une manière uniforme de raisonner applicable à tous les sujets sur lesquels l'esprit humanin peut s'exercer [positive philosophy (or scientific knowledge), in which I include the study of social phenomena as well as of all other kinds of phenomena, indicates a uniform manner of thinking applicable to all subjects that the mind can deal with]. (p. viii) 
As noted in the statement above, social phenomena are not incompatible with or unfit for scientific, certain knowledge.

The second recurrent misunderstanding alluding to interpretivism, after the subjective/objective dichotomy, hinges on the belief that interpretivism cannot provide generalizable results, or plainly put, a qualitative researcher is unable to generalize. Foregrounding the role of generalization in qualitative research, Yin (2014), a prominent figure of research method, recently specified that interpretivists or qualitative researchers can shed light on the theory and principles under study by using or offering analytic generalization. Thus, with analytic generalizations or to use an expression of Seddon and Scheepers (2015) "inductive generalizations" (p. 37), interpretivists can -- as they usually do - yield conclusions and recommendations with resonance or applicability well beyond the case or context at hand. It follows that defining generalizability as the equivalent or monopoly of numbers is the same as limiting the complexity of reality to numbers. More clearly, Yin (2014) described generalizability with the idea of lessons learned. In fact, interpretivistic work embodies a wealth of lessons learned needed for a better understanding of the world in which we live. Some authors have proposed terms such as resonance (Mason, 2002; Tracy, 2010, 2013) or transferability (Denzin \& Lincoln, 2018a).

Still other authors (Roy et al., 2015) have portrayed the findings garnered in qualitative research as findings that are "portable, moving from ... one specific context out toward... other contexts" (p. 255). It is thus inescapably acknowledged that qualitative research can yield generalizable or portable findings. The concept lessons learned presupposes that qualitative researchers regard generalizability as the process of learning from prior research to improve the world and the knowledge thereof. The reason being that social scientists seek to gain a deeper understanding of people from an in-depth experience of a few individuals. Qualitative social research is research with a deeper general understanding (i.e., generalization), an understanding that sheds light on events, individuals and societies across contexts. The goal is to "help counter the view that generalization beyond the immediate evidence and the case is impossible in qualitative research" (Bryman, 2016, p. 399). A deeper understanding of one phenomenon or individual can very well illuminate other individuals across the larger population or wider society.

The third and last misunderstanding pertaining to interpretivism holds that numbers, graphs, tables and the like are not germane to interpretivistic knowledge, but rather they are exclusively designed for quantitative, positivistic knowledge. To put it another way, "descriptive [qualitative] data [is that] which can be observed, but not measured. It can include text, images, sound, etc. but not numerical/quantitative values" (Guijt, 2014, p. i). Thus, it can be said that in quantitative inquiry numbers, tables and graphs are used to identify and illustrate the extent to which the reached findings or conclusions represent the larger population. However, with a purpose to supply deeper and thicker knowledge about that which is being studied, "qualitative researchers use semiotics, narrative, content, discourse, archival and phonemic analysis - even statistics, tables, graphs, and numbers [emphasis added]" (Denzin \& Lincoln, 2018a, p. 12). More specifically, an interpretive researcher employs visuals, that is: numbers, tables, graphs, pictures, audios, etc. with the goal not to generalize findings to the larger population, but rather "to ensure an in-depth understanding of the phenomenon in question [emphasis added]" (Denzin \& Lincoln, 2011, p. 5). By and large, quantitative visuals seek to determine the extent to which a research's findings reflect the larger population whereas qualitative visuals seek to enhance the understanding of the phenomenon under study.

\section{Methodology}

This paper undertook a content analysis of literature to take stock of ways or patterns in which capability approach was regarded. To this effect, using Google engine, the paper performed thematic analysis to "search for themes or patterns" (Braun \& Clarke, 2006, p. 2) located in capability approach body of works. For focus purposes, collected themes or patterns were identified along the lines of concepts most dominant in capability approach literature, such as capability, functioning, freedom, opportunity, life, development, and welfare. Equally, the concepts method, worldview, paradigm, and research were searched in wider social science materials to best situate and focus on the paper's key aim. Collected themes provided a state-of-the-art picture of how capability approach was being treated. Armed with these patterns, the paper examined Sen works with an eye on methodological underpinnings to diagnose the existing conditions of capability approach. 


\section{Results and Discussion}

This section seeks to reposition capability approach. The positions vindicated above have set the stage for a deeper discussion of concerned literature in the hopes of repositioning capability approach. To this effect, two steps are taken: background and criticisms.

Background: A better understanding of capability approach can be gained by looking at its background. While capability approach as an approach has not gripped the attention of authors till the 2000s (Nussbaum, 2000, 2003, 2006a, b), it hearkens as earlier back as several decades ago in1959 when Sen defended his doctoral dissertation (Sen, 1960). Indeed, Sen (1960) raised important methodological issues crippling the field of development economics, when he remarked that the tendency of researchers and policy makers to make statements in broad strokes about the development of nations require a rethink of the methods used. More than half a century after Sen statement, renowned methodologist Patton (2015) advocated for research with "emphasis on in-depth understanding of specific cases" (p. 53). Without doubt, interpretive, qualitative research was a leitmotiv preoccupation of Sen since early on. However, this fact tends to escape the attention of authors interested in or familiar with capability approach. For example, Sen (1960) highlighted that the social and cultural heterogeneity alternatively dubbed variability or contextuality is key to a deeper understanding of individuals and their societies. This remark has been underestimated not only in research method and development literature as seen earlier but also in capability approach materials. Capability approach undertakes a radical departure from a means-centric orientation to one of fuller human realization (Sen, 2012). Instead, researchers prefer numbers or abstract indicators of local particularities. Consequently, Sen (1960) warned, "in fact, it is not quite clear what one means by the physical quantity of capital since the producer [of] goods and their products are both quite heterogeneous" (p. 17).

Put differently, the quantity of capital (or development or wellbeing) does not represent the variability proper or endogenous to a society and its members. Such a warning by Sen continues to reverberate to this day among critics of quantitative research. Most pertinently, Cosgrove, Wheeler and Kosterina (2015) bemoaned the "hegemony of quantification" (p. 17) seen in most social science materials. So, as explained above, quantification ought to reflect the variability of the larger population. This is the context in which the idea of capability has come to be a core tenet of capability approach. Capability approach "has to take a direct interest in the lives [emphasis added] that people are actually able to lead" (Sen, 2012, pp. 102-103) or live. Capability approach is more about the quality of people's life than the quantity, quantification, or simplification of it. Capability approach bears ample testament to the idea that capabilities are not so much about the things distributed, purchased, possessed, amassed, enjoyed, or accessed, as they are about life lived fuller and better. This implies that a society's worst-off individuals have the actual ability to live fuller and better lives. By the same token, this requires a researcher's sustained attention to and rendition of locales and particularities. One key in ensuring that research dovetails with selected locales and corresponding particularities is to allow for broader choices or capabilities among individuals in order for a nation's members to live fuller and better lives. This is what Sen $(1979 a, b, 1999,2009,2012)$ endeavoured to do for much of his life.

As Nussbaum (2003) argued, although growth indicators or numbers can be beneficial they do not increase our understanding of what a society's individuals are actually able (to choose) to be and accomplish under day-today circumstances. The core nature of capability approach is best encapsulated in the definition of qualitative research. A key idea worth a closer look and yet often bypassed is the idea that capability approach amounts to qualitative research. As is apparent throughout this paper, there is a vast mass of hitherto untapped imperial evidence showcasing how capability approach squarely fits in with qualitative research. One compelling illustration is with the definition of qualitative research. As Erickson (2018) delineated,

Qualitative research seeks to discover and to describe narratively what particular people do in their everyday lives... From Latin, qualitas refers to a primary focus on the qualities, the features, of entities to distinctions in kind --- while the contrasting term, quantitas, refers to a primary focus on differences in amount... The qualitative researcher first asks, "What are the kinds of things (material or symbolic) to which people in this setting orient as they conduct everyday life?". The quantitative researcher first asks, "How many instances of a certain kind [of things] are there here?". (p. 36) 
As observed above, needless to say that capability approach rests on and engages with the quality of life that people are able to live in everyday life. As Sen (2009) posited,

Capability approach focuses on human lives, and not just on the resources people have, in the form of owning - or having use of - objects of convenience that a person may possess. Income and wealth are often taken to be the main criteria of human success. By proposing a fundamental shift in the focus of attention from the means of living to the actual opportunities a person has, the capability approach aims at a fairly radical change... It also initiates a very substantial departure from the means-orientation [emphasis in original]. (p. 253)

As shown in the above explanation, quality of life distinguishes capability approach from an approach with a vested interest in the quantity of things cherished par excellence in quantitative research. The idea for qualitative research is, as Erickson (2018) added, to "be describing everyday life from the points of view [or accounts] of those who lived it" (p. 40). Life lived and defined from the perspectives of those concerned is another potent description of qualitative research, namely interpretive, qualitative research. As presented earlier, the word interpretive has served as a modifier of qualitative research, in the aftermath of the school of social research called verstehende Soziologie created by German sociologists Simmel (1908) and Weber (1921/2002).

Since in German the verb verstehen is also synonymous with the verb interpretieren (see Duden, https://www.duden.de), verstehende Soziologie stands for interpretierende Soziologie [interpreting Sociology], with the latter being most commonly rendered as interpretive sociology. "It is not possible to chronologically and semantically distinguish Simmel from Weber in their usage of the term interpretive sociology, since they each presented significantly similar and contemporary insights of the term" (Cibangu, 2012, p. 105). Because capability approach seeks to give an account of and shed light on everyday life lived by the poor from the perspectives of the poor, it comes down to interpretive, qualitative research. The notion of interpreting sociology being "durch Verstehen Andrer und Verstanden werden [through understanding of others and being understood]" (Simmel, 1908, p. 674) bears out the idea of presenting and relating to the points of view of those being researched.

Criticisms: As indicated earlier, while capability approach has its origins in Sen doctoral dissertation in 1959 (Sen, 1960), it has not been explicitly discussed till the 2000s. Indeed, since the 2000s, three dominant criticisms have been voiced on the subject of capability approach: (1) operationalization of capabilities, (2) list of capabilities, and (3) theoretical framework. First, the operationalization of capabilities (Alkire, 2016; Anand, Santos, \& Smith, 2009; Jacobson, 2016; Kleine, 2010) is the idea that capability approach should be expressed in the form of concepts that can be measured by researchers. These concepts are called operational definitions or operational concepts because they represent a set of activities or operations characterizing the relations observed between selected variables in a given experiment or research. Thus, the central question becomes "how do we measure capabilities?" (Anand, Santos, \& Smith, 2009, p. 284). While the issue of capabilities operationalization has surfaced since the early stages of capability approach, it has not been discussed within the methodological paradigm of positivism in which it is rooted. This paper was filling this gap by resituating the concept operational definitions within the paradigm of positivistic, quantitative research because capability approach corresponds to interpretive, qualitative research. As a matter of fact, attempts to operationalize capabilities not only have displayed limited results, but they have met with increasing resistance even among quantitative researchers.

As Anand, Santos and Smith (2009) acknowledged, "there remain areas of application where further questions could be devised, but the questions developed and analyzed to date nonetheless illustrate which economic statistics the capabilities approach requires for its operationalization within quantitative empirical work [emphasis added]" (p. 303). As stated in this remark, operationalization of capability is nothing less than the positivistic, quantitative paradigm being applied behind the façade of capability approach. As Kuklys (2005) articulated, capability approach is founded on a paradigm or philosophical foundation that is different from that of welfare economics wherein much of the conversation about operationalization takes place. To explain, operational definition is a concept inherited from positivistic arenas with the goal to measure or manipulate a unit of analysis in a lab or lab-like environment and thus produce replicable propositions. As Nobel-Prize 
physicist Bridgman (1927) stressed, "all results of measurement are only approximate... Any statement about numerical relations between measured quantities must always be the subject of the qualification that the relation is valid only within limits [emphasis added]" (p. 33). As is clear from the observation above, measurement just like positivism described earlier cannot and should not lay claim to certainty. However, by immersing themselves in reality, interpretive, qualitative researchers seek not a manipulation or distortion of reality, but rather a deeper, thicker understanding of it.

The totalitarian pursuit of measurement seen in capability approach literature (details above) is challenged by the variability of the world and people within and beyond experiment. As Jacobson (2016) corroborated, "given that capabilities and functioning may vary across social circumstances, measures must vary [emphasis added]. Some researchers are frustrated by the flexibility of this approach" (pp. 797-798). Therefore, the operationalization of capability approach exhibits two major shortcomings. On the one hand, the operationalization of capability approach amounts to nothing but the incorporation of capability approach into the paradigm of positivistic, quantitative research. While such an endeavour might have merits, it betrays the hallmark of capability approach seen throughout Sen writings. Indeed, scores of capability approach analysts have been calling for a broader methodological range within capability approach literature (Adler \& Fleurbaey, 2016). On the other hand, the operationalization of capability approach falls short of tackling endogeneity, more precisely the ability of any quantitative research to accurately represent the variability of the larger population from which a research's sample has been derived. While the discussions homed in on the statistical relations between capability indicators or between capability and well-being variables (Anand, Santos, \& Smith, 2009) might be beneficial, they should match up to the standards of quantitative research, namely the ability of any sample to duly represent the variability of the larger population.

Sure enough, one of the leading champions of measurement involving capability approach is Alkire (2016). In a cogent conclusion, Alkire (2016) warned that it is not the nature of capability approach to measure or preselect capabilities. It follows from this that capability approach is by definition an open-ended, nontotalitarian, or flexible approach -- something which falls entirely within the lead feature of interpretive, qualitative inquiry. As Patton (2015) asserted, qualitative approach has at its core the openness of inquiry allowing open-ended questions or interviews and open eyes and minds to enable the researcher to investigate reality the deepest. It is time to liberate capability approach from the dominion of positivistic paradigm. It is time to invest research efforts and resources in "the value of methodological breadth" (Adler \& Fleurbaey, 2016, p. 17) or variety. Only then can capability approach spawn new spaces and voices of capabilities. As Denzin and Lincoln (2018b) maintained,

It is once again time to move forward into an uncertain, open-ended utopian future. It is time to open up new spaces, time to decolonize the academy, time to create new spaces for indigenous voices, time to explore new discourses, new politics of identity, new concepts of equity and social justice, new forms of critical ethnography, new performance stages... We must renew our efforts to honor the voices of those who have been silenced by dominant paradigms. (p.x)

As noted in the statement above, the idea that capability approach does not measure or cannot be measured is nothing less than a single space and thus a misleading view of the approach. Most interesting is the fact that in defending the idea of measuring well-being using capability approach, the term space is proposed. Indeed, Alkire (2016) "argues that well-being and its lack should be measured in the space of capabilities... and so affirms the powerful ongoing relevance of capabilities as a space for the evaluation of well-being at the present time [emphasis added]" (p. 616). As described above, space connotes the idea of flexibility, movability, openness, or freedom needed to apply and reflect capabilities and particularities in wide-ranging contexts.

The second dominant criticism raised against capability approach, after that regarding the operationalization of capabilities, has to do with the list of capabilities or to borrow a poignant description of Simon et al. (2013) "a comprehensive or appropriate general set of capabilities" (p. 188). Perhaps the most known list of capabilities proposed to date is that of Nussbaum $(1997,2000,2006 a, b)$, which is composed of ten central capabilities: (1) life, (2) bodily health, (3) bodily integrity, (4) senses, (5) emotions, (6) practical reason, (7) affiliation, (8) other species, (9) play, and (10) control over one's environment (Nussbaum, 2006b, pp. 76-78). 
Nevertheless, despite her staunch campaign for a comprehensive list of capabilities, Nussbaum $(1997,2000$, 2006a, b) clarified that any specific list of capabilities ought to allow for openness or multiple applicability, all of which in fact is the hallmark of interpretive, qualitative research and of capability approach. The observation resonates well with Sen (2004) apt response to the idea of listing capabilities, when he declared,

It would be a mistake to build a mausoleum for a "fixed and final" list of capabilities usable for every purpose and unaffected by the progress of understanding [emphasis added] of the social role and importance of different capabilities. The problem is not with listing important capabilities, but with insisting on one predetermined canonical list of capabilities, chosen by theorists without any general social discussion or public reasoning. To have such a fixed list, emanating entirely from pure theory, is to deny the possibility of fruitful public participation on what should be included and why. (p. 77)

As explained above, contextuality defeats the reason behind the list of capabilities. If capabilities are contingent on locality, there is no apparent reason for imposing or proposing a selected, universal, or context-free list of capabilities in order for capability approach to become an approach. As Kleine (2013) argued, "reduction in complexity is particularly evident in quantitative studies [of capability approach] using aggregate data. Qualitative research may be in a better position to mirror the approach's complexity" (p. 29). Quantitative applications of capability approach undermine the complexity and richness of the approach.

The third and last dominant criticism made about capability approach refers to theoretical framework. This criticism consists in the "fundamental question that Sen's approach does not fully answer: how do individual and collective choice relate to each other?" (Kleine, 2013, p. 28). It is believed that, as Kleine (2013) expounded, capability approach does not have a theoretical framework. Thus, by supplying capability approach with a framework, a capability approach researcher is likely not only to preserve the open-endedness of development practice, but more specifically to ensure the choices of the individuals involved in the process. This requires not just a framework, but a critical, flexible framework. As Denzin and Lincoln (2018b) specified, "a critical framework is central to this project. It speaks for and with those who are on the margins" (p.x).

Critical framework comes from a research method that liberates individuals from hegemonic positivism. To this effect, some critics have been advocating for "a wider conceptual framework" (Diga \& May, 2016, p. 2). A wider conceptual framework is a framework in which no one paradigm has the monopoly of what and how to operationalize and frame research and its concepts. Despite stern remarks that capability approach is no way a quantitative research method, as noted earlier, the rate of attempts to quantify the fundamental concepts of capability approach has rocketed. As Nussbaum (2006b) postulated, quantitative measurement would not do justice to the complexity and open-mindedness of capability approach. Most rightfully, after crafting the framework designed to fix or complement capability approach, Kleine (2013) called for more in-depth work about the proposed grand framework of capability approach in order to avoid "a 'one-size-fits-all-(more or less)' approach" (Kleine, 2013, p. 205). As is now clear, a grand framework of capability approach, although attractive, clashes not only with research method principles but with capability approach itself. Perhaps to make matters worse, the proposed framework (Kleine, 2013, p. 44) lacks Nussbaum (2006b) ten central capabilities, let alone a concept as vast as structure listed on the framework - to take just one example comprises only five elements. This point validates Popper (1994/1996b) warning about framework -- a warning found in his well-known book published on The Myth of Framework that states that a grand framework is unlikely to lead to a productive discussion since participants tend to be more allegiant to the framework than they are sensitive to reality or contextuality.

Popper (1994/1996b) expanded on the idea that a framework is a function of contextuality. What contextuality does is that it brings into the research process different sensitivities, different nuances, different lenses, different sediments, etc. that render the gained knowledge deeper, thicker, or to use a preferred word of Husserl (1913/2002) sedimented. Sedimented knowledge is knowledge that goes past mere layers to include deposits, traces, curves, turns, dots, holes, etc. that in the course of time have made the bedrock or foundation of a structure or phenomenon. In sum, efforts towards an operationalization of capability approach, an exhaustive list of capabilities and an all-encompassing framework of capability approach are all but concepts cherrypicked from positivism with the goal to subsume capability approach under the hegemony of quantification or quantitative research. For example, phenomenology is an approach well-known for its 
interpretivistic distinctive feature, but researchers do not ask nor expect Husserl (1913/2002) the founder of phenomenology to do things such as to (1) operationalize phenomena, (2) present a comprehensive list of phenomena, and (3) craft an all-encompassing theoretical framework regarding phenomena. The same is true of many if not all interpretive authors and their central concepts, such as Ricoeur (1969) and the concept meaning, Marx (1867/1977) and social class conflict, Bourdieu (1986) and social capital, Foucault $(1969 / 1972)$ and discourse, etc. Nor do researchers require the aforementioned interpretive schools of thought to present recipes for statistical, quantitative measurements of their respective concepts and arguments thereof. To be clear, if none of these and similar authors of interpretivism are not blamed, for example, for being unable to operationalize the central concept of their line of thought, it is thus unfair and indeed unproductive for researchers to demand that capability approach do the things that are not demanded of others.

Perhaps one best way around the temptation of paradigmatic or methodological imperialism endemic in capability approach circles is to use mixed method, a method in which capability approach can keep its inalienable nature of interpretivism. That "one of the main critiques against the [capability] approach is the difficulty of its operationalization" (Ibrahim, 2014, p. 15), cannot be blamed on capability approach but rather on a broader methodological problem wrecking statistics and more precisely positivism. The idea being, "not everything that can be counted counts, and not everything that counts can be counted" (Cameron, 1963, p. 13). This is because "capabilities need to be built from the bottom-up" (Ibrahim, 2017, p. 197). Bottom-up refers to contextuality, and numbers are abstractions if not distortions of the myriad sensitivities embedded in contextuality. In a study unrelated to capability approach - which shows that this is not a problem of capability approach, Miles, Huberman \& Saldaña (2014) affirmed that numbers (or measurement units so to speak) are all but one aspect of details among myriads that make up the layers and contours beneath participants' reality. This confirms the premier feature of capability approach, which questions the methodologies being used about development. In this sense, "this [capability] approach outlines the purpose of development to enlarge opportunities for people and facilitate an environment where people can enjoy what they value in life" (Tiwari, 2017, p. 185).

While tremendous success has been accomplished across disciplines in ways of conceptualizing development as a fuller expansion of substantive freedoms, the methodologies via which capability approach is being implemented have yet to be conducive to pluralism and ensuing openness, creativity, or flexibility. This is because in recent decades, as Denzin and Giardina (2017) stipulated, "the emphasis on metrics and deliverables has never been more prevalent" (p. 3). Paradigm pluralism is a privileged tool in gaining a deeper understanding of modern day (development) problems and making the world a better place. In fact, the last decades have seen an increased awareness vis-à-vis the multidimensionality of development indexes and policies (Alkire et al., 2015). Yet, multidimensionality that does not involve research paradigms is incomplete if not corrosive. For most capability approach literature regards methodology as a mere exposé of specific statistical details such as the relations between selected indicators of capabilities and those of functioning, and vice versa. Thus, capability approach scholarship is bedeviled by grievous blind spots as to how on the one hand a sample represents the larger population (global diversity), and how, on the other hand, research paradigms are discussed to ensure or enhance the interpretive, qualitative cachet of capability approach.

\section{Conclusion and Recommendations}

Although capability approach has been gaining ground among social science experts of differing persuasions, it has met with a number of deep rooted criticisms. Three chief criticisms often aired against capability approach are that it lacks (1) a recipe of operationalization, (2) a list of capabilities, and (3) a comprehensive theoretical framework. Notwithstanding implacable calls for broader methodological space from within research method venues in general and capability approach literatures in particular, discussions of statistical minutiae such as those over capability indicators and functioning indicators have proliferated, and positivism has prevailed in capability approach outlets. This paper took capability approach back to its interpretivistic roots rather than rehashing positivism. Curiously enough, the conclusions or clarifications made by Sen and by his detractors about the criticisms leveled against capability approach result in the emphasis being placed on the idea of openness or contextuality, an earmark of qualitative research. 
For a long time, capability approach has been resisting deportation from its native land of interpretivism, shall I say, leaving attempts of capability measurements trapped in a vicious cycle. It is because discussions of research method have been given little to no attention among capability approach analysts that misjudgments vis-à-vis capability approach have abounded. The blame if any for the pitfalls associated with measurement ought to be directed at the paradigm looming behind a given research and its processes, and not at capability approach. This paper was not denying the necessity of discussions concerned with operationalization and similar concepts. Rather the paper was recommending that such discussions ensure paradigm pluralism as well as the interpretive, qualitative feature of capability approach. It was also recommended that authors engage with methodological underpinnings of capability approach literature bearing in mind how positivism was/is subtly influential if not tyrannical. Without a discussion on and exposé of methodological underpinnings, capability approach will act as a springboard for positivistic agenda.

\section{References}

Adler, D. M. \& Fleurbaey, M. (2016). Introduction. In M. D. Adler \& M. Fleurbaey (Eds.), The Oxford handbook of well-being and public policy (pp. 1-18). New York, NY: Oxford University Press.

Alkire, S. (2002). Valuing freedoms: Sen's capability approach and poverty reduction. New York, NY: Oxford University Press.

Alkire, S. (2005a). Why the capability approach? Journal of Human Development, 6(1), 115-135.

Alkire, S. (2005b). Subjective quantitative studies of human agency. Social Indicators Research, 74(1), 217-260.

Alkire, S. (2008a). Choosing dimensions: The capability approach and multidimensional poverty. In N. Kakwani, Nanak, \& J. Silber (Eds.), The many dimensions of poverty (pp. 89-119). New York, NY: PalgraveMacMillan.

Alikre, S. (2008b). Using the capability approach: Prospective and evaluative perspectives. In F. Comim, M. Qizilbash, \& S. Alkire (Eds.), The capability approach: Concepts, measures and applications (pp. 26-50). New York, NY: Cambridge University Press.

Alkire, S. (2010a). Instrumental freedoms and human capabilities. In S.L. Esquith \& F. Gifford (Eds.), Capabilities, power, and institutions (pp. 18-32). University Park, PA: Pennsylvania State University Press.

Alkire, S. (2010b). Human development: Definitions, critiques, and related concepts. Development Program Research Paper 2010/01 Retrieved from UN Development Program sitehttps://core.ac.uk/download/pdf/6248643.pdf

Alkire, S. (2010c). Development: A misconceived theory can kill. In C.W. Morris (Ed.), Amartya Sen (pp. 191220). New York, NY: Cambridge University Press.

Alkire, S. (2016). The capability approach and well-being measurement for public policy. In M. D. Adler \& M. Fleurbaey (Eds.), The Oxford handbook of well-being and public policy (pp. 615-644). New York, NY: Oxford University Press.

Alkire, S. \& Black, R. (1997). A practical reasoning theory of development ethics: Furthering the capabilities approach. Journal of International Development, 9(2), 263-279.

Alkire, S., Foster, E. J., Seth, S., Santos, E. M., Roche, M. J. \& Ballon, P. (2015). Multidimensional poverty index: Measurement and analysis. New York, NY: Oxford University Press.

Alkire, S., Qizilbash, M. \& Comim, F. (2008). Introduction. In F. Comim, M. Qizilbash, \& S. Alkire (Eds.), The capability approach: Concepts, measures and applications (pp. 1-25). New York, NY: Cambridge University Press.

Anand, P., Santos, C. \& Smith, R. (2009). The Measurement of capabilities. In K. Basu \& R. Kanbur (Eds.), Arguments for a better world: Essays in honor of Amartya Sen (1, 283-310). New York, NY: Oxford University Press.

Babbie, R. E. (2016). The practice of social research (14th ed.). Boston, MA: Cengage.

Bacon, F. (1889). Novum organum (edited by T. Fowler, 2nd ed.). Oxford, UK: Clarendon Press. (Original work published 1620)

Bamberger, M. (2000). Integrating quantitative and qualitative research in development projects. Washington, DC: World Bank.

Bates, J. M. (1999). The invisible substrate of information science. Journal of the American Society for Information Science, 50(12), 1043-1050. 
Bourdieu, P. (1986). The forms of capital. In J.G. Richardson (Ed.), Handbook of theory and research for the sociology of education (pp. 57-60). New York, NY: Greenwood Press.

Braun, V. \& Clarke, V. (2006). Using thematic analysis in psychology. Qualitative Research in Psychology, 3(2), 77-101.

Bridgman, W. P. (1927). The logic of modern physics. New York, NY: Macmillan.

Bryant, A. (2017). Grounded theory and grounded theorizing: Pragmatism in research practice. New York, NY: Oxford University Press.

Bryman, A. (2016). Social research methods (5th ed.). New York, NY: Oxford University Press.

Cameron, W. B. (1963). Informal sociology: A casual introduction to sociological thinking. New York, NY: Random House.

Cibangu, K. S. (2012). Qualitative research: The toolkit of theories in the social sciences. In A. López-Varela (Ed.), Theoretical and methodological approaches to social sciences and knowledge management (pp. 95-126). London, UK: InTech.

Chiappero-Martinetti, E., Budd, H. C. \& Ziegler, R. (2017). Social innovation and the capability approach: Introduction to the special issue. Journal of Human Development and Capabilities, 18(2), 141-147.

Clandinin, J. D. (2016). Engaging in narrative inquiry. New York, NY: Routledge.

Comte, A. (1830). Cours de philosophie positive: Tome 1er. Les préliminaires généraux et la philosophie mathématique. Paris: Bachelier.

Comte, A. (1998). Discours sur l'ensemble du positivisme. Paris: Editions GF. (Original work published 1848)

Cosgrove, L., Wheeler, E. E. \& Kosterina, E. (2015). Quantitative methods: Science means and ends. In I. Parker (Ed.), Handbook of critical psychology (pp. 15-23). New York, NY: Routledge.

De Herdt, T. (2008). Social policy and the ability to appear in public without shame: Some lessons from a food relief program in Kinshasa. In F. Comim, M. Qizilbash, \& S. Alkire (Eds.), The capability approach: Concepts, measures and applications (pp. 458-488). New York, NY: Cambridge University Press.

Denzin, K. N. (2014). Interpretive autoethnography (2nd ed.). Thousand Oaks, CA: Sage.

Denzin, K. N. \& Giardina, D. M. (2017). Introduction: Qualitative inquiry in neoliberal times. In N.K. Denzin \& M.D. Giardina (Eds.), Qualitative inquiry in neoliberal times (pp. 1-16). New York, NY: Routledge.

Denzin, K. N. \& Lincoln, S. Y. (2011). Introduction: The discipline and practice of qualitative research. In N.K. Denzin. \& Y. S. Lincoln (Eds.), The Sage handbook of qualitative research (4th ed., pp. 1-19). Thousand Oaks, CA: Sage.

Denzin, K. N. \& Lincoln, S. Y. (2018a). Introduction: The discipline and practice of qualitative research. In N.K. Denzin \& Y.S. Lincoln, (Eds.), The Sage handbook of qualitative research (5th ed., pp. 1-26). Thousand Oaks, CA: Sage.

Denzin, K. N. \& Lincoln, S. Y. (2018b). Preface. In N.K. Denzin \& Y.S. Lincoln, (Eds.), The Sage handbook of qualitative research (5th ed., pp. ix-xx). Thousand Oaks, CA: Sage.

Denzin, K. N. \& Lincoln, S. Y. (2018c). Locating the field. In N.K. Denzin \& Y.S. Lincoln, (Eds.), The Sage handbook of qualitative research (5th ed., pp. 27-35). Thousand Oaks, CA: Sage.

Denzin, K. N. \& Lincoln, S. Y. (2018d). Paradigms and perspectives in contention. In N. K. Denzin \& Y.S. Lincoln, (Eds.), The Sage handbook of qualitative research (5th ed., pp. 97-107). Thousand Oaks, CA: Sage.

Descartes, R. (1987). Discours de la méthode: Pour bien conduire sa raison et chercher de la vérité dans les sciences (Texte et commentaire par Etienne Gilson). Paris: Vrin. (Original work published 1637)

Diga, K. \& May, J. (2016). The ICT ecosystem: The application, usefulness, and future of an evolving concept. Information Technology for Development, 22(sup 1), 1-6.

Durkheim, E. (1982). The rules of sociological method: And selected texts on sociology and its method (W.D. Halls, Trans.). London, UK: Macmillan. (Original work published 1895)

Eberle, T. S. (1999). Die methodologische Grundlegung der interpretativen Sozialforschung durch die phänomenologische Lebensweltanalyse von Alfred Schütz. Osterreichische Zeitschrift fürSoziologie, 24(4), 65-90.

Enderle, G. (2013). The capability approach as guidance for corporate ethics. In C. Luetge (Ed.), Handbook of the philosophical foundations of business ethics (pp. 675-691). New York, NY: Springer.

Engel, S. (2017). Shame, poverty and development studies. Journal of International Development, 29(8), 12151226.

Erickson, F. (2018). A history of qualitative research in social and educational research. In N.K. Denzin \& Y.S. Lincoln, (Eds.), The Sage handbook of qualitative research (5th ed., pp. 36-65). Thousand Oaks, CA: Sage. 
Foucault, M. (1972). The archaeology of knowledge (A.M. Sheridan, Trans.). London: Tavistock. (Original work published 1969)

Friedman, M. (1999). Reconsidering logical positivism. New York, NY: Cambridge University Press.

Fukuda-Parr, S., Yamin, E. A. \& Greenstein, J. (2014). The power of numbers: A critical review of Millennium Development Goal targets for human development and human rights. Journal of Human Development and Capabilities, 15(2-3), 105-117.

Guba, G. E. \& Lincoln, Y. S. (1988). Do inquiry paradigms imply inquiry methodologies? In D. Fetterman (Ed.), Qualitative approaches to evaluation in education (pp. 89-115). New York, NY: Praeger.

Guba, G. E. \& Lincoln, S. Y. (2005). Paradigmatic controversies, contradictions, and emerging confluences. In N.K. Denzin \& Y.S. Lincoln (Eds.), The Sage handbook of qualitative research (3rd ed., pp. 191-215). Thousand Oaks, CA: Sage.

Guijt, I. (2014). Participatory approaches, methodological briefs: Impact evaluation 5. Florence, Italy: UNICEF.

Habermas, J. (1971). Knowledge and human interests (J. J. Shapiro, Trans.), Beacon Press, Boston, MA. (Original work published 1968)

Hammersley, M. (2013). The myth of research-based policy and practice. Thousand Oaks, CA: Sage.

Hansen, A. \& Machin, D. (2013). Media and communication research methods. New York, NY: Palgrave Macmillan.

Heisenberg, W. (1927). Über den anschaulichen Inhalt der quantentheoretischen Kinematik und Mechanik. Zeitschrift für Physik, 43(3-4), 172-198.

Heisenberg, W. (2001). Die physikalische Prinzipien der Quantentheorie. Berlin: Spektrum. (Original work published 1930)

Hirai, T., Comim, F. \& Ikemoto, Y. (2016). Happiness and human development: A capability perspective. Journal of International Development, 28(7), 1155-1169.

Holland, J. \& Campbell, R.J. (2005). Contexts and challenges for combining methods in development research. In J. Holland \& J.R. Campbell (Eds.), Methods in development research: Combining qualitative and quantitative approaches (pp. 1-18). Rugby, UK: ITDG.

Horkheimer, M. \& Adorno, W.T. (1972). Dialectic of enlightenment (J. Cumming, Trans.). New York, NY: Continuum. (Original work published 1947)

Husserl, E. (2002a). Die Idee des Phänomenologie und phänomenologischen Philosophie. Aller Teile: Allgemeine Einführung in die reine Phänomenologie (6 Aufl., unveränd. Nachdr. der 2. Aufl. 1922). Tübingen, Germany: Max Niemeyer. (Original work published 1913)

Ibrahim, S. (2006). From individual to collective capabilities: The capability approach as a conceptual framework for self-help. Journal of Human Development, 7(3), 397-416.

Ibrahim, S. (2014). The capability approach: From theory to practice-rationale, review and reflections. In S. Ibrahim \& M. Tiwari (Eds.), Capability approach: From theory to practice (pp. 1-28). New York, NY: Palgrave Macmillan.

Ibrahim, S. (2017). How to build collective capabilities: The 3C-Model for grassroots-led development. Journal of Human Development and Capabilities, 18(2), 197-222.

Jacobson, L. T. (2016). Amartya Sen's capabilities approach and communication for development and social change. Journal of Communication, 66(5), 789-810.

Jastrow, J. (1901). Fact and fable in psychology. London, UK: Macmillan.

Johnson, S. \& Rasulova, S. (2017). Qualitative research and the evaluation of development impact: incorporating authenticity into the assessment of rigour. Journal of Development Effectiveness, 9(2), 263-276.

Kleine, D. (2010). ICT4What? Using the choice framework to operationalize the capabilities approach to development. Journal of International Development, 22, 674-692.

Kleine, D. (2013). Technologies of choice: ICTs, development, and the capabilities approach. Cambridge, MA: MIT.

Kuklys, W. (2005). Amartya Sen's capability approach: Theoretical insights and empirical applications, studies in choice and welfare. New York, NY: Springer.

Lange, S. \& Klasen, S. (2015). How the new international goal for child mortality is unfair to Africa (again). Center for Global Development Working Paper 407.

Lévi-Strauss, C. (1995). Myth and meaning: Cracking the code of culture (with a new foreword by W. Doniger). New York, NY: Schocken Books. (Original work published 1978)

Lewis, T. C. \& Short, C. (1879). A Latin dictionary: Founded on Andrews' edition of Freund's Latin dictionary: Revised, enlarged, and in great part rewritten. Oxford, UK: Clarendon Press. 
Liddell, G. H. \& Scott, R. (1996). A Greek-English lexicon (9th ed.). New York, NY: Oxford University Press. (Original work published 1843)

Lincoln, S. Y., Lynham, A. S. \& Guba, G. E. (2018). Paradigmatic controversies, contradictions, and emerging confluences, revisited. In N.K. Denzin \& Y.S. Lincoln, (Eds.), The Sage handbook of qualitative research (5th ed., pp. 108-150). Thousand Oaks, CA: Sage.

Lindlof, R. T. \& Taylor, C. B. (2011). Qualitative communication research methods (3rd ed.). Thousand Oaks, CA: Sage.

Loots, S. \& Walker, M. (2016). A capabilities-based gender equality policy for higher education: Conceptual and methodological considerations. Journal of Human Development and Capabilities, 17(2), 260-277.

Marx, K. (1977). Capital: A critique of political economy (B. Fowkes, Trans.). New York, NY: Vintage Books. (Original work published 1867)

Marx, K. (1978). These über Feuerbach. In Institut für Marxismus-Leninismus beim Zentralkomitee (ZK) der Kommunistischen Partei der Sowjetunion (KPdSU), Karl Marx Friedrich Engels Werke (Vol. 3, pp. 5-7). Berlin: Dietz Verlag. (Original work published 1845)

Mason, J. (2002). Qualitative researching (2nd ed.). Thousand Oaks, CA: Sage.

Mayoux, L. \& Chambers, R. (2005). Reversing the paradigm: Quantification, participatory methods and propoor impact assessment. Journal of International Development, 17(2), 271-298.

Miles, B. M., Huberman, A. M. \& Saldaña, J. (2014). Qualitative data analysis: A methods sourcebook (3rd ed.). Thousand Oaks, CA: Sage.

Morgan, L. M. (2007). Paradigms lost and pragmatism regained: Methodological implications of combining qualitative and quantitative methods. Journal of Mixed Methods Research, 1(1), 48-76.

Nussbaum, C. M. (1997). Capabilities and human rights. Fordham Law Review, 66(2), 273-300.

Nussbaum, C. M. (2000). Women and human development: The capabilities approach. New York, NY: Cambridge University Press.

Nussbaum, C. M. (2003). Capabilities as fundamental entitlements: Sen and social justice. Feminist Economics, 9(2-3), 33-59.

Nussbaum, C. M. (2006a). Education and democratic citizenship: Capabilities and quality education. Journal of Human Development, 7(3), 385-395.

Nussbaum, C. M. (2006b). Frontiers of justice: Disability, nationality, and species membership. Cambridge, MA: Harvard University Press.

Nussbaum, M. (2011). Creating capabilities: The human development approach. Cambridge, MA: Belknap Press.

Nussbaum, M. (2013). Political emotions: Why love matters for justice. Cambridge, MA: Belknap Press.

Nussbaum, C. M. (2014). Introduction: Capabilities, challenges, and the omnipresence of political liberalism. In F. Comin \& M. Nussbaum (Eds.), Capabilities, gender, equality (pp. 1-16). New York, NY: Cambridge University Press.

Nussbaum, M. (2016). Anger and forgiveness: Resentment, generosity, justice. New York, NY: Oxford University Press.

OECD. (2011). Divided we stand: Why inequality keeps rising. Paris: OECD.

Patton, Q. M. (2015). Qualitative research and evaluation methods: Integrating theory and practice (4th ed.). Thousand Oaks, CA: Sage.

Popper, R. K. (1996a). In search of a better world: Lectures and essays from thirty years. New York, NY: Routledge. (Original work published 1994)

Popper, R. K. (1996b). The myth of framework: In defence of science and rationality. New York, NY: Routledge. (Original work published 1994)

Popper, R. K. (2002). Conjectures and Refutations: The Growth of Scientific Knowledge. New York, NY: Routledge. (Original work published 1963)

Pressman, S. \& Summerfield, G. (2009). The economic contributions of Amartya Sen. In S. Pressman (Ed.), Leading contemporary economists: Economists at the cutting edge (pp. 66-98). New York, NY: Routledge.

Qizilbash, M. (2006). Capability, happiness and adaptation in Sen and J. S. Mill. Utilitas, 18(01), 20-32.

Qizilbash, M. (2011). Sugden's critique of Sen's capability approach and the dangers of libertarian paternalism. International Review of Economics, 58(1), 21-42.

Qizilbash, M. (2012). The capability approach: Its interpretation and limitations. In K. Gelber \& F. Panzironi (Eds.), The capability approach: Development practice \& public policy in the Asia-Pacific Region (pp. 9-22). New York, NY: Routledge. 
Qizilbash, M. (2013). On capability and the good life: Theoretical debates and their practical implications. Philosophy and Public Policy Quarterly, 31(2), 35-42.

Qizilbash, M. (2016). Capability, objectivity and "false consciousness": On Sen, Marx and J.S. Mill. International Journal of Social Economics, 43(12), 1207-1218.

Reeb, D., Sakakibara, M. \& Mahmood, I. P. (2012). From the editors: Endogeneity in international business research. Journal of International Business Studies, 43(3), 211-218.

Ricoeur, P. (1969). Le conflit des interprétations: Essais d'herméneutique I. Paris: Seuil.

Robeyns, I. (2005). The capability approach: A theoretical survey. Journal of Human Development and Capabilities, 6(1), 93-117.

Robeyns, I. (2009). Justice as fairness and the capability approach. In K. Basu \& R. Kanbur (Eds.), Arguments for a better world. essays for Amartya Sen's 75th birthday (pp. 397-413). New York, NY: Oxford University Press.

Robeyns, I. (2016). Capabilitarianism. Journal of Human Development and Capabilities, 17(3), 397-414.

Robeyns, I. (2017). Wellbeing, freedom and social justice: The capability approach re-examined. Cambridge, UK: Open Book.

Roy, K., Zvonkovic, A., Goldberg, A., Sharp, E. \& LaRossa, R. (2015). Sampling richness and qualitative integrity: Challenges for research with families. Journal of Marriage and Family, 77(1), 243-260.

Rubin, E. (1915). Synsoplevede Figurer: Studier i psykologisk Analyse. Første Del [Visually experienced figures: Studies in psychological analysis. Part one]. Copenhagen, Denmark: Gyldendalske Boghandel, Nordisk Forlag.

Seddon, B. P. \& Scheepers, R. (2015). Generalization in IS research: A critique of the conflicting positions of Lee \& Baskerville and Tsang \& Williams. Journal of Information Technology, 30, 30-43.

Sen, K. A. (1960). Choice of techniques: An aspect of the theory of planned economic development. Oxford, UK: Basil Blackwell.

Sen, K. A. (1979a). Utilitarianism and welfarism. The Journal of Philosophy, 76(9), 463-489.

Sen, K. A. (1979b). Equality of what. Retrieved from http://tannerlectures.utah.edu/_documents/a-toz/s/sen86.pdf

Sen, K. A. (1981). Public action and the quality of life in developing countries. Bulletin of Economics and Statistics, 43(4), 287-319.

Sen, K. A. (1982). Poverty and famines: An essay on entitlement and deprivation. New York, NY: Oxford University Press.

Sen, K. A. (1984a). The living standard. Oxford Economic Papers, 36(S0), 74-90.

Sen, K. A. (1984b). Resources, values and development. Cambridge, MA: Harvard University Press.

Sen, K. A. (1985a). Well-being, agency and freedom: The Dewey lectures 1984. Moral information. The Journal of Philosophy, 82(4), 169-221.

Sen, K. A. (1985b). Commodities and capabilities. Oxford, UK: Elsevier Science.

Sen, K. A. (1987). The standard of living. Cambridge, UK: Cambridge University Press.

Sen, K. A. (1988). The concept of development. In H.B. Chenery \& T.N. Srinivasan (Eds.), Handbook of development economics (Vol. 1, pp. 9-26).

Sen, K. A. (1989). Development as capability expansion. Journal of Development Planning, 19, 41-58.

Sen, K. A. (1992). Inequality re-examined. New York, NY: Oxford University Press.

Sen, K. A. (1993). Markets and freedoms: Achievements and limitations of the market mechanism in promoting individual freedoms. Oxford Economic Papers, 45(4), 519-541.

Sen, K. A. (1995). Rationality and social choice. American Economic Review, 85(1), 1-24.

Sen, K. A. (1997). From income inequality to economic inequality. Southern Economic Journal, 64(2), 383-401.

Sen, K. A. (1999). Development as freedom. New York, NY: Random House.

Sen, K. A. (2004). Capabilities, lists and public reason: Continuing the conversation. Feminist Economics, 10(3), 77-80.

Sen, K. A. (2009). The idea of justice. Cambridge, MA: Harvard University Press.

Sen, K. A. (2012). Values and justice. Journal of Economic Methodology, 19(2), 101-108.

Sen, K. A. \& Williams, B. (1982). Introduction: Utilitarianism and beyond. In A.K. Sen \& B. Williams (Eds.), Utilitarianism and beyond (pp. 1-22). New York, NY: Cambridge University Press.

Simmel, G. (1908). Soziologie: Untersuchungen über die Formen derVergesellschaftung, Duncker \& Humblot, Leipzig, Germany. 
Simon, J., Anand, P., Gray A., Rugkåsa J., Yeeles K. \& Burns T. (2013). Operationalizing the capability approach for outcome measurement in mental health research. Social Science \& Medicine, 98, 187-196.

Skovdal, M. \& Cornish, F. (2015) Qualitative research for development: A guide for practitioners. Rugby, UK: Practical Action.

Smith, J. M. (1998). Social science in question. Thousand Oaks, CA: Sage.

Smith, J. M. (2005a). Empiricism, idealism, realism. In: M.J. Smith (Ed.), Philosophy and methodology of the social sciences. Vol. 4: Reinventing the social sciences: Towards a post disciplinary future (pp. 319367). Thousand Oaks, CA: Sage.

Smith, J. M. (2005b). Knowing, the known and knowledge of the social. In: M.J. Smith (Ed.), Philosophy and methodology of the social sciences. Vol. 4: Reinventing the social sciences: Towards a post disciplinary future (pp. xvii-xli). Thousand Oaks, CA: Sage.

Sotos, C. E. A., Vanhoof, S., Van den Noortgate, W. \& Onghena, P. (2007). Students' misconceptions of statistical inference: A review of the empirical evidence from research on statistics education. Educational Research Review, 2(2), 98-113.

Sustainable Development Goals. (2015). Retrieved from https://sustainabledevelopment.un.org/?menu=1300

The Millennium Development Goals. (2000). Retrieved from http://www.un.org/en/events/pastevents/millennium_summit.shtml

Tiwari, M. (2017). Exploring the role of the capability approach in social innovation. Journal of Human Development and Capabilities, 18(2), 181-196.

Tracy, J. S. (2010). Qualitative quality: Eight "Big-Tent" criteria for excellent qualitative research. Qualitative Inquiry, 16(10), 837-851.

Tracy, J. S. (2013). Qualitative research methods: Collecting evidence, crafting analysis, and communicating impact. Malden, MA: Wiley-Blackwell.

van der Mark, J. E., Conradie, I., Dedding, W. M. C. \& Broerse, W. E. J. (2017). How poverty shapes caring for a disabled child: A narrative literature review. Journal of International Development, 29(8), 1187-1206.

Van der Tuin, I. (2013). Non-reductive continental naturalism in the contemporary humanities: Working with Hélène Metzger's philosophical reflections. History of the Human Sciences, 26(2), 88-105.

Venkatapuram, S. (2011). Health justice: An argument from the capabilities approach. Cambridge, MA: Polity.

Venkatapuram, S. (2014). Mental disability, human rights and the capabilities approach: Searching for the foundations. International Review of Psychiatry, 26(4), 408-414.

Vicari, S. (2014). The co-operative as institution for human development: The case study of Coppalj, a primary co-operative in Brazil. Journal of International Development, 26(5), 683-700.

Walker, M. \& Unterhalter, E. (2007). The capability approach: Its potential for work in education. In M. Walker \& E. Unterhalter (Eds.), Amartya Sen's capability approach and social justice in education (pp. 1-18). New York, NY: Palgrave Macmillan.

Wallach, W. (2015). A dangerous master: How to keep technology from slipping beyond our control. New York, NY: Basic Books.

Weber, M. (1949). Critical studies in the logic of the cultural sciences: A critique of Eduard Meyer's methodological views. In E. Shils \& H.A. Finch (Eds.), Max Weber on the methodology of the social sciences (pp. 113-188). New York, NY: The Free Press.

Weber, M. (2002). Wirtschaft und Gesellschaft: Grundni $\beta$ der verstehende Soziologie (fünfte, revidierte Auflage besorgt von Johannes Winckelmann). Tübingen, Germany: Mohr Siebeck. (Original work published 1921).

Welche Thiere gleichen einander am moisten, (1892). Fliegende Blätter, 17(2465), 147.

Wittgenstein, L. (1958). Philosophical investigations (with the German text, 2nd ed., G.E.M. Anscombe, Trans.). Oxford, UK: Basil Blackwell. (Original work published 1953). 